\title{
$\begin{array}{lllll}\mathrm{P} & \mathrm{R} & \mathrm{O} & \mathrm{S} & \mathrm{A}\end{array}$
}

U G O G I O R G E T T I

\section{A MAIS BELA MORTE}

Um informe de algum departamento de saúde pública de Buenos Aires, das primeiras horas do dia 10 de março, quinta-feira última, dizia laconicamente: "ao redor das 2.26 desta madrugada, através da central 107 chegou uma solicitação de auxílio, vinda de um restaurante na rua Olga Cossetini, 791, e a informação de que havia uma pessoa caída. Uma ambulância chegou ao local, providenciou os primeiros socorros e constatou que se tratava do senhor Roberto Perfumo, que tinha sofrido um traumatismo craniano". Assim se relatava sua morte à maneira protocolar da burocracia de Estado. Descrevia-se a morte do "senhor Roberto Perfumo", como se fosse a morte de qualquer um, apenas uma entre todas as mortes que a cada noite acontecem nas grandes capitais do mundo. Uma descrição para fazer parte das estatísticas e pronto. A edição do Clarin vinha cheia de homenagens, causadas pelo choque do falecimento de um ídolo nacional. Não faltaram recordações de sua classe e citaçôes de seus feitos no Racing, no Cruzeiro de Belo Horizonte, no River e na seleção argentina. Sempre acreditei que jogadores de defesa devem ser mais inteligentes do que jogadores de ataque. Um jogador de defesa burro é uma tragédia em potencial. $\mathrm{O}$ defensor tem que se antecipar ao atacante, tem que imaginar, e mesmo adivinhar, o que o atacante vai fazer, prever o desfecho do lance e chegar primeiro na bola. Depois deve, numa fração de segundo, decidir o que fazer: chutão ou passe. E sempre fazer o certo. Inteligência, portanto, e não só vigor físico, é o que necessita um jogador de defesa. Por isso são tão raros. Pode parecer até uma contradição, mas revelações na zaga são mais difíceis de acontecer do que revelaçôes de atacantes. Infelizmente, nem dirigentes, nem mesmo treinadores se convencem disso. É comum ver times investindo tudo no ataque, enchendo seus elencos com atacantes e nenhum defensor realmente de qualidade. Porque é difícil, repito. Roberto Perfumo foi um desses grandes jogadores. Zagueiro consagrado na Argentina chegou no Cruzeiro em 1971. Eu o vi jogar diversas vezes. Chegava junto, com o vigor dos jogadores argentinos, mas saía jogando com a mesma eficiência. Foi um dos maiores. Sua morte me entristece muito, como deve entristecer a todos que gostam de futebol. Mas, ao mesmo tempo, me alegra na mesma intensidade. Todo mundo, pelo menos que conheço, pede por uma morte rápida, indolor e quase inadvertida. Outro dia um amigo meu conversava com a mulher e a irmã serenamente na sala da casa quando, de repente, caiu fulminado por um aneurisma. É sem dúvida uma 


\section{$\begin{array}{lllll}\mathrm{P} & \mathrm{R} & \mathrm{O} & \mathrm{S} & \mathrm{A}\end{array}$}

morte aceitável. Há quem prefira, e mesmo imagine, uma morte dormindo. Uma noite se vai para cama, despreocupado como um justo, talvez levando um livro, ou mesmo um ebook e depois de algumas linhas apaga-se a luz e o mundo cessa de existir, já que nunca mais se acorda. Também é uma morte que evita sofrimento, agonia, desgaste e dor. Mas há outra morte e essa me parece a melhor, a desejada. Que tal você se reunir com amigos, daqueles amigos que o acompanham por toda a vida numa cantina italiana, pedir sua pasta preferida bem al dente, seu vinho mais apreciado e atravessar horas rindo e se divertindo com os velhos companheiros? Daí você pede, de sobremesa, uma pastiera di grano, um café e, lá pelas duas da manhã, começa a sair do restaurante. Não chega a sair, não chega sequer a interromper o riso que surgiu com a última piada. A escada à sua frente é seu caminho para o nada. Você cai por ela sem perceber que está morto. Foi exatamente desse jeito, aos 73 anos de idade, saindo de uma cantina italiana de Buenos Aires, às duas da manhã, alegre e rodeado de amigos que morreu Roberto Alfredo Perfumo. Você seria capaz de imaginar uma morte melhor para um grande boleiro? Você seria capaz de imaginar morte melhor para qualquer um?

\section{UM POUCO DE FICÇÃO}

Terça-feira à noite, nervoso com um noticiário confuso na tv, do qual não entendia quase nada, o homem resolveu deixar o apartamento para ir, talvez, ao supermercado. Às terças lhe é permitido fazer pequenos passeios. Saiu do seu apartamento sem esquecer, como pessoa respeitável, de se colocar em paletó e gravata. Ao abrir-se a porta do elevador o homem impulsivamente deu um passo para dentro e imediatamente viu-se rodeado de uma grande quantidade de pessoas alegres, carregando garrafas de Champagne, falando e rindo alto com copos nas mãos. Aturdido tentou voltar, mas a porta do elevador se fechou e ele viu que subia. Não podia entender o que falavam. Nada pior para um homem pouco familiarizado com um idioma, do que pessoas falando ao seu redor ao mesmo tempo. A confusão de vozes é fatal. E lá foi ele entre multimilionários, loucos de alegria, meio incrédulos, que se abraçavam. Sem poder fazer nada deixou-se abraçar e ficou contente de reconhecer uma cara que já tinha visto. $\mathrm{O}$ conhecido se aproximou e o cumprimentou afavelmente. Foi nesse momento que a porta do elevador se abriu e o bloco de pessoas o arrastou para dentro de outro apartamento. Reconheceu a cobertura, que já tinha visto em fotos e que secretamente almejava um dia visitar. A algazarra dentro do magnífico apartamento em mármore branco era indescritível. Perdido, tateando, ele 


\section{$\begin{array}{lllll}\mathrm{P} & \mathrm{R} & \mathrm{O} & \mathrm{S} & \mathrm{A}\end{array}$}

permaneceu vagamente por lá. Não via muita gente da sua idade, mas viu imediatamente ele. Ele, o seu vizinho ilustre, cercado por jovens e não tão jovens, com sua cara e seu penteado inconfundíveis. Chegou mais perto do vizinho e ali ficou olhando para ele em silêncio embasbacado. Os olhos do vizinho cruzaram os seus e ele então sorriu, o conhecido sorriso brasileiro diante de um estrangeiro, simpático, reverente, cheio de gratuita e calorosa admiração. $\mathrm{O}$ sorriso fez o efeito esperado. $\mathrm{O}$ vizinho chamou alguém que estava por ali, justamente a pessoa que o havia cumprimentado no elevador e com quem já tinha esbarrado. Ouviu, sem compreender bem, o vizinho perguntar olhando para ele: Who's this? Seu conhecido replicou: "The ex president". O vizinho poderoso olhou para ele atônito: "ex president? E o interlocutor, talvez julgando um pouco complicado explicar o que era a CBF resolveu resumir: "from Brazil". O vizinho ficou muito admirado e alegremente surpreendido. "Brazil?!”. Ergueu-se de onde estava, evitou alguns abraços e aproximou-se estendendo as mãos. $\mathrm{O}$ nosso homem tinha lágrimas nos olhos e no sorriso fixo. Jamais poderia supor que, sobretudo nos dias atribulados pelos quais passava, o destino lhe fosse oferecer ocasião tão rara. A conversa, se essa é a palavra, se desenvolveu entre os dois numa curiosa mistura de expressões de simpatia em novayorkês de rua e respostas em hesitantes grunhidos num inequívoco paulistês. Mas isso não tinha nenhuma importância. O que interessava é que estava lá. Lembrou, num esforço, que estava em pleno dia das eleiçôes americanas. Não tinha podido pensar muito nisso, ocupado com reuniōes com advogados, mas agora se dava conta. Maravilhado viu que era alguém importante nas primeiras comemorações íntimas da eleição. Reparou que pessoas já olhavam para ele com atenção, algumas até lhe dirigiram a palavra. Inutilmente: o barulho era muito e o conhecimento do inglês pouco. Mas podia reconhecer claramente coisas como "president" e "Brazil". Por um instante esqueceu até da tornozeleira. Pensou em descer ao seu apartamento e convidar a esposa para a reunião. Mas logo lhe ocorreu um velho provérbio de seu mundo passado: em time que está ganhando não se mexe. Resolveu então ficar apenas por ali, e gozar a felicidade. E foi assim que José Maria Marin entrou na história, na noite de terça-feira última em Nova Iorque. Afinal ele e Donald Trump moram no mesmo prédio.

Ugo Giorgetti (São Paulo, 1942) é cineasta. Fez cerca de 20 filmes, sendo 12 deles longa-metragens, com destaque para Sábado (1994), Boleiros (1998), Festa (1989), O príncipe (2002) e Cara e coroa (2012). Graças a Boleiros, foi convidado a escrever uma coluna semanal sobre futebol no jornal $\mathrm{O}$ Estado de S.Paulo, que continua saindo todos os domingos. A crônicas aqui republicadas são exemplos de colunas escritas em épocas mais ou menos recentes: A mais bela morte (11/3/2016); Um pouco de ficção (11/11/2016). Foi artista residente do IdEA - Instituto de Estudos Avançados, da Universidade Estadual de Campinas (Unicamp), de agosto a novembro de 2018. 